is of course desirable as a way of getting financially responsible defendants, but the tendency of such a scheme to rapidly augment the costs of insurance must also be considered..$^{8}$ In general these changes would require legislation and raise constitutional objections which, however, are not insuperable. A satisfactory appraisal of the necessity and expediency of such a plan must await an investigation similar to that made as a basis for the auto compensation plan. Until then the public must be content with judicial protection which grows increasingly satisfactory.

To go from no liability to absolute liability within a hundred years is no small step. Perhaps Lord Abinger had this in mind when he said: "Unless we confine the operations of such contracts as this to the parties who entered into them, the most absurd and outrageous consequences, to which I can see no limit, would ensue." 39

\title{
SURETYSHIP RELEASES IN THE IAW OF MORTGAGES
}

Recent application of a familiar suretyship rule to cases in which a mortgagor's grantee had not assumed the mortgage debt offers a practical reason for investigating the bases of the rule..$^{x}$ This rule-releasing a surety when, without his consent, the creditor has contracted to extend time to the principal debtor-has frequently been the target of authoritative criticism. ${ }^{2}$ Little or no attention, however, has been paid to its mortgages counterpart-releasing a mortgagor when time has been extended by the mortgagee to a grantee of the mortgaged land. A discussion of the desirability of releasing a mortgagor involves an examination not only of the propriety of the analogy but of the reasons for the suretyship rule and its application in practice. Even though the analogy may be found to be a poor one, the frequency with which courts extend the suretyship rule to mortgage cases and the desirable results reached in certain of these cases ${ }^{3}$ make an inquiry into the nature and scope of the suretyship rule a necessary preliminary.

\section{THE SURETYSHIP RULE}

THE SURETY'S LOSS OF RIGHTS

Regardless of the rule's comparatively modern origin in $1789^{4}$ it is usually considered a well-settled doctrine of suretyship. 5 The traditional justification

${ }^{8}$ Under a compulsory automobile insurance plan in Massachusetts the cost of insurance doubled. Lilly, op. cit. supra note 36 .

${ }^{39}$ Winterbottom v. Wright, тo M. \& W. I09, II3 (I842).

× Kazunas v. Wright, 286 Ill. App. 554, 4 N.E. (2d) II8 (1936).

2 Cardozo, The Nature of the Judicial Process $x_{53}$ (I925); 4 Williston, Contracts $\& 1225$ (2d ed. 1936); Durfee, Book Review, I7 Corn. L. Q. 707 (1932).

${ }^{3}$ See p. 479 sulpra.

4 Nisbet v. Smith, 2 Bro. C.C. 579 ( 7789 ); Ames, Cases on Suretyship 156, n. I (I90r).

${ }^{3} 4$ Williston, Contracts $\S 1222$ (2d ed. 1936 ). 
of the rule is that the creditor has deprived the surety of his right of subrogation, i.e., the right to sue the principal debtor in the creditor's name after payment to the creditor. ${ }^{6}$ Today, however, the surety has a well-recognized right to proceed directly against the debtor after he has paid the creditor-the right of indemnity. ${ }^{7}$ Courts have nevertheless continued to talk of loss of the right of subrogation as the main justification for releasing the surety. This is probably an historical accident: when the first case (Nisbet $v . S^{2}$ ith $^{8}$ ) was decided, the only well-established ground on which the surety could sue the principal debtor was his equitable right of subrogation.9 Although one earlier case had recognized the surety's right of indemnity by allowing an action in assumpsit on the debtor's implied promise, ${ }^{\mathrm{x}}$ this right was not generally recognized until I799. II But even today the right of subrogation does offer one benefit not obtainable by resort to the right of indemnity: if the creditor has security ${ }^{12}$ or other priority rights, ${ }^{13}$ a suit in his name will give the surety these additional protections.

In releasing a surety because of his loss of a right of subrogation, all courts have assumed that the mere making of an extension agreement destroys the surety's ability to obtain this right. ${ }^{14}$ Since the creditor may be enjoined ${ }^{x 5}$ from suing the debtor during the extension period, it is said that he has no rights against the debtor which the surety could obtain by paying the debt. ${ }^{16}$ But the mere fact that the creditor may be personally enjoined need not necessarily have implied that the creditor's preferred rights may not be obtained from him by a surety who was not a party to the extension agreement. However, even if the surety could obtain these rights, it would still be an open question whether the debtor could prevent him from exerting them. No cases have been found in

${ }^{6}$ Overend v. Oriental Financial Corp., L.R. 7 H.L. 348 (I874); Swire v. Redman, I Q.B.D. 536 (I876).

7 Appleton v. Bascom, 3 Metc. (Mass.) I69 (I84I); Blanchard v. Blanchard, 20I N.Y. I34, 94 N.E. 630 (I9II); Lloyd, The Surety, 66 U. of Pa. L. Rev. 40 (I9I7).

$8_{2}$ Bro. C. C. 578 ( $\mathrm{I}_{7} 89$ ).

9 Rees v. Berrington, 2 Ves. Jr. 540 (I 795); $c f$. Scot v. Stephenson, I Lev. 7 I (I662); Ames, History of Assumpsit, 3 Selected Essays 259, 287 (Igog).

${ }^{20}$ Decker v. Pope, I Sel. N.P. 9I (13th ed. 1757); Walsh, History of Anglo-American Law 346 (2d ed. x932).

Ir Exall v. Partridge, 8 T.R. 308 (I 799); see Stirling v. Forrester, 3 Bligh 575, 590 (I821).

12 Allen v. Powell, ro8 IIl. 584 ( 1884 ). It should be noted that this feature is present in all mortgage cases.

${ }_{33}$ Love v. North American Co., 229 Fed. ro3 (C.C.A. 8th I9r5); Smith v. Davis, 7 I W.Va. 316, 76 S.E. 670 (I9I2); 37 Harv. L. Rev. 259 (I923).

14 Swire v. Redman, I Q.B.D. 536 ( 1876 ).

Is 3 Williston, Contracts $\S{ }_{1} 844$ (I920). In some states this extension agreement constitutes a legal defense to the creditor's action. Strobridge Lithographing Co. v. Randall, 78 Mich. I95, 44 N.W. 134 (1889).

${ }^{16}$ Edwards v. Goode, 228 Fed. 664 (C.C.A. 5th rgr6). 
which the surety has paid and then attempted to use the creditor's priority rights during the extension period; thus the true disposition of the surety's right of subrogation remains unknown..$^{\mathrm{x}}$

It has been shown that today the right of subrogation is valuable only to give the surety the priority rights which the creditor may have had. But the creditor will probably resort to a surety only where no security or other priority right is available for his protection. In such a case, it should be shown that the surety has suffered the loss of some other "right" before his release may justifiably be said to be necessary for his protection.

The next most important right of the surety which might possibly be affected by an extension of time is his right to be indemnified by the debtor after he has paid the creditor. Since, as shown above, the creditor cannot sue the surety, ${ }^{18}$ the only way in which the surety's right to be indemnified can arise is for the surety voluntarily to pay the creditor. Perhaps most courts in saying that the "right of subrogation" is lost as a result of the extension agreement are again referring to the right of indemnity. But it is difficult to understand how a contractual right between the surety and the debtor can be destroyed by a contract between the debtor and the creditor. ${ }^{19}$ Thus where the right of subrogation had been destroyed by the statute of limitations, the surety has been allowed to indemnify himself by proceeding against the debtor. ${ }^{20}$ However, business men do not normally pay debts unless a demand is made; thus the absence of facts necessary to give rise to a clear-cut case on the state of the right of indemnity, voluntary payment by the surety, makes the value of this right speculative and its loss negligible. ${ }^{2 x}$

The surety also has the right by bill quia timet (right of exoneration) to force the debtor to pay the creditor when there is threatened inability or refusal on the part of the principal debtor to pay the matured debt, thus protecting himself from possibly increased liability. ${ }^{22}$ When the maturity date is extended by an agreement, a possible defense to a suit by the surety during the extension period would be that the debt is not yet due. ${ }^{23}$ But this is of course reasoning in

17 Tenderness for the debtor who has paid consideration not to be sued might possibly be the ground for giving the surety the same rights as the debtor, i.e., an injunction during the extension period. 4 Williston, Contracts $\S$ I225 (2d ed. r936).

${ }^{18} \mathrm{It}$ is curious to note that failure of the surety to use his right of subrogation (indemnity) results from his release, yet release is based on the loss of this right.

${ }^{29} 4$ Williston, Contracts $\S \mathrm{r} 225$ (2d ed. 1936). Comparable though slightly different considerations apply to the rights of the non-consensual surety against the principal.

${ }^{20}$ Hyde v. Miller, 45 App. Div. 396, 60 N.Y.S. 974 (1899); see also American Surety Co. v. De Carle, 25 F. (2d) 18, 20 (C.C.A. 9th 1928); United States Fidelity and Guaranty Co. v. Centropolis Bank, I7 F. (2d) 9I3, 916 (C.C.A. 8th I927).

${ }^{2 x}$ Cardozo, The Nature of the Judicial Process ${ }_{54}$ (x925); Swire v. Redman, I Q.B.D. $53^{6}$ (1876).

22 West Huntsville Cotton Mills v. Alter, I64 Ala. 305, 5 I So. 338 (Igro).

${ }^{23}$ Note to Nisbet v. Smith, 2 Bro. C.C. 578,583 ( 7789 ). 
a circle; and again it would seem impossible for an agreement between the creditor and the debtor to cut off the rights of a third party, the surety. ${ }^{24}$ Here, too, the surety will rarely resort to this right and, even if it were cut off by the extension agreement, this seems an insufficient reason for releasing the surety.

Finally, there is an anomalous right, reputedly derived from Pain v. Pack$a r d{ }^{25}$ by which the surety may request the creditor to sue the debtor and, if the creditor fails to sue within a reasonable (or statutory) period, the surety is released. This right has been severely criticized ${ }^{26}$ but it has received judicial recognition in a few states and statutory recognition in others, though subject everywhere to significant exceptions or limitations. ${ }^{27}$ The presence of an extension agreement makes such a request by the surety useless because the debtor has a valid defense to the creditor's action. Thus, the use of this right is impaired by the extension agreement but its scattered recognition, general disfavor and rare use make this an insufficient basis on which to release the surety.

Even assuming that as a result of the extension agreement the surety has lost one of these four rights which might have been of practical value to him, he is not entitled to protection against loss of the right unless he would have attempted to use it. When he did not know of the extension agreement and failed to exert any of these rights, in no sense has the surety actually been deprived of anything sufficiently valuable to justify his release. Yet, when the surety has received no notice of the extension agreement until long after the period has expired, courts in the automatic application of the rule have released him from liability.28

The surety's actual injury in any case is at most only the difference between the size of the debtor's purse at maturity and at the end of the extension agreement. Since it is difficult to measure relative degrees of insolvency, ${ }^{29}$ a complete release might be considered a practical working rule..$^{30}$ This has certain prophylactic benefits, ${ }^{3 x}$ since it will discourage the giving of extension agreements without the knowledge and consent of the surety. But where the debtor was insolvent at maturity to the same extent as later, there has been no injury to the surety and release seems unjustified. Nevertheless, application of the

24 See 4 Williston, Contracts $\S$ I225 (2d ed. r936).

${ }^{25}$ I3 Johns. (N.Y.) I74 (I8I6).

${ }^{26}$ The creditor usually seeks a surety to secure prompt payment without resorting to litigation. See r Rocky Mt. L. Rev. 232 (1929); Smith v. Freyler, 4 Mont. 489, I Pac. 214 (1883).

${ }_{27}^{2}$ See 37 Yale L.J. 97x (I928).

${ }_{28}$ Barden v. Sworts, II2 Misc. 384 , 183 N.Y.S. 184 (I920); Kazunas v. Wright, $286 \mathrm{IIl}$. App. 554, 4 N.E. (2d) rI8 (1936) (mortgagor learned of extension agreement eight years after it was made).

${ }^{29} C f$. American Surety Co. v. Greek Union, ${ }_{284}$ U.S. ${ }_{53}$ (1932).

${ }^{30}$ Samuell v. Howarth, 3 Mer. 272 (1817); Polak v. Everett, I Q.B.D. 669 (I876).

${ }^{3 x}$ Polak v. Everett, I Q.B.D. 669 (1876); Paine v. Jones, 76 N.Y. 274 (I879). 
rule in early cases released the surety in this situation. ${ }^{32}$ Furthermore, since courts do not mention or investigate the debtor's finances, the debtor's comparative worth has not been used as the determinant of the surety's loss. This lack of investigation of the debtor's finances in early cases makes it appear that these courts were applying a simple general rule.

\section{INTENTION TO RELEASE THE SURETY}

Since the creditor, by reserving his rights against the surety in the extension agreement, may avoid releasing the surety it may be argued that the surety is being released because an intention so to do is presumed from the absence of any provision in the ordinary agreement as to his liability. ${ }^{33}$ This inference as to the intention of a practical business man, drawn from his failure to reserve rights against the surety is unfounded. Perhaps this fictional construction of intent has as its sole justification the doctrine of strictissimi juris: that the accommodation surety is the favorite of the law. ${ }^{34}$ But even admitting this to be an untenable inference as to the creditor's intention, it is so easy to include a reservation of rights against the surety in the extension agreement that this may well be considered simply a rule of convenience.

\section{INCREASED RISK}

In the ordinary case the surety is protected in that the debtor, not having the benefit of an extension agreement with the creditor, is apt to pay, and the creditor is apt to take action at the most opportune moment, i.e., when the debtor is most able to pay. Where there is an extension agreement, however, the debtor will not pay at maturity ${ }^{35}$ nor may the creditor sue at the most opportune moment. Thus in this sense it might be said that the extension agreement increases the surety's risk. ${ }^{36}$ But where there is mere delay, ${ }^{37}$ even delay until the creditor's claim is barred by the statute of limitations, ${ }^{38}$ or failure to

${ }^{32}$ Swire v. Redman, I Q.B.D. 536 (r876).

33 Hodges v. Elyton Land Co., Iog Ala. 6I7, 20 So. 23 ( 1895 ). An alternative reason for not releasing the surety when rights are reserved against him is that the extension agreement is construed solely as a covenant that the creditor will not personally sue the debtor. Arant, Suretyship 296 (r93r).

${ }^{34}$ Shreffler v. Nadelhoffer, I33 Ill. 536, 25 N.E. 630 (1890); but see Belloni v. Freeborn, 63 N.Y. 383,387 ( 1875 ); 2 Williston, Contracts $\S 602$ ( 1920 ).

35 Arant, Suretyship 287 (I93I).

${ }^{36}$ It has also been suggested that the surety's duties should be regarded as limited by the terms of his agreement. Since this agreement usually contains no provision for an extension of time, it may be argued that the extension changes a term in the surety's agreement, entitling the surety to a release. Arant, Suretyship 287 (I93I). The argument seems, however, to beg the question.

37 Bank of Utica v. Ives, I7 Wend. (N.Y.) 5 or (1837).

${ }^{38}$ Villars v. Palmer, 67 Ill. 204 (I873); 3 Minn. L. Rev. 534 (I9I9); 77 U. of Pa. L. Rev. I033 (rg29). 
file a claim against a bankrupt's estate, ${ }^{39}$ or the estate of a decedent, ${ }^{40}$ the surety is not released. If the surety can be said to have bargained for some degree of protective care on the part of the creditor, this protection is limited by the possibility of the creditor's being induced to bind himself not to sue. The creditor's consideration can vary from the debtor's promise not to pay until the expiration of the extension period $4^{4}$ to a substantial payment, and variations in the amount of the consideration will affect its influence on the creditor's judgment and concern for the surety. In view of the reluctance of courts to consider varying values of consideration and of the difficulties of calculating such risks, there is not likely to be any adequate determination of true degrees of risk. Furthermore, this theory loses force in the case of a binding agreement to extend time made with a third person ${ }^{42}$ not the debtor, or extensions made by the court ${ }^{43}$ because the surety is not released. Mr. Justice Holmes seems to have used the converse of this argument in denying release where the possibility of this increased risk was contemplated in the contract. ${ }^{44}$ A California court has expressed somewhat the same idea in denying release on the ground that because the extension of time was for the benefit of the surety, the consent of the surety could be implied. 45 Prof. Durfee, in a criticism of "the increase of risk" justification ${ }^{4}$ for the rule, states that extension agreements, obviously not unusual, should always be a contemplated risk, especially since "No surety pleading this defense (actual harm) has ever made the beginning of a showing of actual injury." 47

IIAUTATIONS UPON THE APPLICATION OF THE SURETYSEIP RULE

Courts have seized every opportunity to limit the suretyship rule ${ }^{48}$ since its application has presented many harsh cases. When the surety company was

39 Duerr v. Sloan, 50 Cal. App. 512, I95 Pac. 475 (I921); 5 Minn. L. Rev. 485 (r921); contra, McCollum v. Hinckly, 9 Vt. $x_{43}$ ( 1837 ) (holding failure to file claim a voluntary release). See Bankruptcy Act $\S 63 ; 30$ Stats. 562 (1898); I I U.S.C.A. $\S$ I03 (b) (I927) (surety is allowed to file contingent claims).

${ }^{40}$ Ray v. Brenner, 12 Kan. 105 (1873); contra, Auchampaugh, Adm'r. v. Schmidt, 70 Iowa 642,27 N.W. 805 (1886); cf. Huddleston v. Frances, I24 Ill. x95, I6 N.E. 243 (I888) (statute).

${ }_{4 \pi}$ Cf. Olmstead v. Latimer, 58 N.Y. $3{ }^{13}, 53$ N.E. 5 (1899).

${ }^{2}$ Frazer v. Jordan, 8 El. \& Bl. 303 (1858); Clark v. Berley, 4I Ch.D. 422 (I889).

43 Kissire v. Grocer Co., ro3 Ark. 473 , 445 S.W. 567 (Igr2).

44 U.S. v. McMullen, 222 U.S. 460, 468 (IgI2); Southern Surety Co.v. Guaranty State Bank, 275 S.W. 436 (Tex. Civ. App. I925); contra, Edwards v. Goode, 228 Fed. 664 (C.C.A. 5th I9I6).

${ }_{45}$ Fruit Growers Supply Co. v. Goss, ${ }_{4}$ Cal. App. (2d) 65I, 4I P. (2d) 357 (1935); contra, Klise Lumber Co. v. Enkema, I48 Minn. 5, I8I N.W. 201 (I920).

${ }^{6}$ Arant, Suretyship 287 ('93I).

47 Durfee, Book Review, I7 Corn. L.Q. 707 (1932); cf. American Surety Co. v. Greek Union, 284 U.S. 563 (1932).

48 "The modification of the rule for commercial sureties to allow recovery only to the extent of the injury is probably attributed in part to the extent of the technical nature of the defense." United States v. United States Fidelity and Guaranty Co., I78 Fed. 72 I (C.C. Pa. IgIo). 
developed, courts discarded the doctrine of strictissimi juris so far as these companies were concerned, both because they were in the business for profit ${ }^{49}$ and because they drew up the instruments..$^{50}$ Since the creditor often paid the premiums to the indemnity company, no intention to release the surety could be found in the extension agreement. Even though these business sureties are considered to have contemplated extensions of time, they are not considered to have made agreements on the matter, since they are released to the extent of their actual damage..$^{5 x}$ Only one case in which damage has been proved has been found, however..$^{52}$ Since such a large proportion of the surety business is carried on today by companies, this is a substantial limitation on the rule releasing sureties.

In similar cases, release has also been denied sureties who have received some sort of compensation. Where the surety is a mere accommodation surety, but has a surety to indemnify him in case he is called on to pay he is not released, ${ }^{53}$ since he is not the simple volunteer the single surety often is. Recently another exception has been made where an important stockholder stands surety for a corporation borrowing money. He is held to receive direct benefit and so is not released.54

In some jurisdictions, the Negotiable Instruments Act has been seized upon as a means of avoiding the rule since extension of time as a defense for a surety was omitted from the Act and hence held to be impliedly discarded. ${ }^{55}$ In view of the saving clause of the Act, leaving the law merchant in force unless expressly revoked, this construction seems a strained one to avoid the rule. The technical and fragile nature of the rule is further shown by the numerous exceptions: a mere reservation of rights against the surety prevents its operation, ${ }^{56}$ unless the creditor knows of the suretyship relation, the surety is not released, ${ }^{57}$ there

49 Standard Salt and Cement Co. v. Surety Co., I34 Minn. I2I, I58 N.W. 802 (19I6); $c f$. Wright v. Shorter, 56 Ga. 72, 76 (1876); New Haven Bank v. Mitchell, I5 Conn. 206 (1842).

${ }^{50}$ Trainor, The Rationale of Corporate and Non-Corporate Suretyship Decisions, 3 Ind. L. Rev. I05, I96 (I927); Arnold, The Compensated Surety, 26 Col. L. Rev. I7I (I926).

sx Murray City v. Banks, 62 Utah 296, 2I9 Pac. 246 (I923).

52 American Surety Co. v. Greek Union, 284 U.S. $5^{6} 3$ (I932).

s3 Kremke v. Radamaker, 60 Okla. I38, I59 Pac. 475 (I9I6); Chilton v. Robbins, 4 Ala. 223 (1842).

54 In re Cancelmo's Estate, 308 Pa. I78, I62 Atl. 454 (I932); First National Bank v. Livermore, 90 Kan. 395, I33 Pac. 734 (Igr3); contra, American Trust Co. v. Louderback, 220 Pa. I97, 69 Atl. 673 (I908).

ss Cellers v. Meachem, 49 Ore. 186, 89 Pac. 426 (1907); Fox v. Terre Haute National Bank, 78 Ind. App. 666, 129 N.E. 33 (1920); Union Trust Co. v. McGinty, 21 2 Mass. 205, 98 N.E. 679 (I912); 43 Yale L. J. Ior 5 (1934); 38 Harv. L. Rev. 954 (1925). See also, Mortgage Guarantee Co. v. Chotiner, 64 P. (2d) 138 (Cal. 1936).

${ }^{56}$ Hodges v. Elyton Land Co., Iog Ala. 617, 20 So. 23 (1896).

57 Morgan v. Thompson, 60 Iowa 280, I4 N.W. 306 (I882); Metz v. Todd, 36 Mich. 473 (1877); Gorenberg v. Hunt, ro7 N.J.Eq. 595, I54 Atl. 630 (r93I). 
must be good consideration, ${ }^{58}$ if there is fraud in procuring the agreement so as not to bind the creditor, the surety is not released, ${ }^{59}$ the release may be waived by the surety after the extension by a mere parol promise without consideration. ${ }^{60}$

The rule releasing a surety on the giving of an extension agreement can be justified only on the grounds that the extension was not a contemplated occurrence and that it removed a bargained-for protection. It should be confined to cases in which it appears that the risk of an extension agreement was not taken by the surety; and the surety should perhaps be released in these cases only to the extent to which he is definitely prejudiced, since it is difficult to speak of increased risk in case of a non-prejudicial extension agreement.

\section{THE MORTGAGE CASES}

With the suretyship rule subject to so many exceptions, ample warning would seem presented to forestall an unconsidering adoption of this rule into mortgage cases. However, there is uniformly less consideration of the rule in mortgage cases than in suretyship cases once the analogy has been set up by the court. Two types of mortgage cases are most often presented: (I) where in acquiring the mortgaged land from the mortgagor, the grantee assumes personal liability for the payment of the debt to the mortgagee; (2) where the grantee merely takes the land subject to the mortgage but does not assume personal liability.

Where the grantee has assumed and promised to pay the mortgage debt, in order to set up a close analogy it is necessary to hold that the mortgagee has a direct right against the grantee, thus making the grantee equivalent to a "principal debtor." This result has been reached on two different bases. (I) Several courts which do not recognize a third party beneficiary's normal position, have allowed the mortgagee to proceed against the grantee on an ill-defined notion of "subrogation." By analogy to the creditor's right to be subrogated to the security given the surety by the debtor, ${ }^{6 x}$ the grantee's promise may be considered an asset of the mortgagor to which the mortgagee may be subrogated..$^{62}$ This reasoning is questionable. For the mortgagor to be a surety, it is necessary that the mortgagee have an independent right against the grantee. Yet for the mortgagee to get this "direct" right by the above analogy, it was necessary to assume that the mortgagor was a surety; thus assuming the conclusion. Other courts using the term "subrogation" avoid treating the mortgagor as a

${ }^{8}$ Hensler v. Watts, Ir $3_{3}$ Towa 74 I, 84 N.W. 666 (r900); Olmstead v. Latimer, I 58 N.Y. $3^{1} 3$, 53 N.E. 5 ( 1899 ).

59 Sandy River Nat'I Bank v. Miller, 82 Me. 137, x9 Atl. Iog (1889).

${ }^{60}$ Culwell v. Edmondson, 22I Ala. 424, 129 So. 276 (r930); Fowler v. Brooks, 13 N.H. 240 (1842).

6x Johnson v. Martin, 83 Wash. 364, r45 Pac. 429 (rgr 5); Union Nat'l Bank v. Rasch, ro6 Mich. 3r9, 64 N.W. 339 (1895).

62 See Walsh, Mortgages 2ro, n. I7 (r934). 
surety by allowing the mortgagee to proceed against the grantee on a theory of equitable execution ${ }^{6_{3}}$ against a mortgagor-debtor's assets. Why the mortgagee is not required to use garnishment or some other form of execution is not explained. With this equitable right of suit of the mortgagee subject in many cases to rescissions of the assumption-contract between the mortgagor and the grantee ${ }^{64}$ it is difficult to consider the grantee a true principal debtor. Thus courts using subrogation notions have considered the suretyship analogy too weak to apply the rule releasing a mortgagor when the mortgagee gives the grantee an extension of time..$^{65}$

(2) In the majority of jurisdictions, however, the mortgagee, as a third party beneficiary, is allowed an action against the grantee on the latter's promise to the mortgagor. ${ }^{66}$ With a direct legal relation between the mortgagee and grantee, an analogy to a true suretyship relation is not as difficult to draw. On this basis most courts release the mortgagor where the mortgagee has given the grantee an extension of time.67 Other courts have recognized a suretyship relation between the mortgagor and grantee but have denied that it has all of its usual consequences for the mortgagee. ${ }^{68}$ They say that by a contract with the grantee the mortgagor does not become a surety as to the mortgagee but that the mortgagee acquires an additional principal debtor and an extension of time to one debtor does not release another. Thus most courts allow the question of release of the mortgagor to be determined simply by the propriety of the suretyship analogy.69

Although these courts have not discussed the bases for releasing a mortgagor when there has been an extension of time, they may have been influenced in reaching this result by the fact that the mortgagor has substantially the same rights as the surety. Thus the mortgagor has a right of subrogation, ${ }^{70}$ valuable in mortgage cases because the mortgaged property constitutes a clear priority

${ }_{3}$ Burr v. Beers, 24 N.Y. ${ }_{7} 8$ (186r).

64 Drury v. Hayden, III U.S. 223 (I884); Thacker v. Hubard, I22 Va. 379, 94 S.E. 929 (I9I8); Hopkins v. Warner, I09 Cal. I33, 4I Pac. 868 (1895); of. Field v. Thistle, 58 N.J.Eq. 339, 43 Atl. 1072 (1899).

65 Wolf v. Murphy, 47 App.D.C. 296 (rgr8); Keller v. Ashford, r33 U.S. 6 ro (r89o).

${ }^{65} 2$ Williston, Contracts $\$ \S 383,384$ (2d ed. r936); see Larson v. Cook, 85 Wis. ${ }_{564}, 55$ N.W. 703 (I893); I5 Harv. L. Rev. 786, 787 (1902).

67 Mississippi Valley Trust Co. v. Bussey, 49 F. (2d) 88I (C.C.A. 5th I93I); Fisher v. Spillman, 85 Kan. 552, II8 Pac. 65 (IgII); Merriam v. Miles, 54 Neb. 566, 74 N.W. 86I (I898).

${ }_{68}$ Pfeifer v. Worthen Co., I89 Ark. 469, 74 S.W. (2d) 220 (r934); Broadman v. Larrabee, 5 I Conn. 39 ( 1883 ); Morganroth v. Pink, 216 Ill. App. 158 (IgIg); Iowa L. \& T. Co. v. Haller, IIg Towa 645,93 N.W. 636 (Ig03).

69 Some courts do not allow the mortgagee to sue the grantee at all and thus would probably not release the mortgagor when there has been an extension of time to the grantee. Codman v. Deland, 23I Mass. 344, I2I N.E. I4 (IgI8); see also In re Errington, [I894] I Q.B. II; Barry v. Harding, I Jones and Lat. 475, 485 (r844) (Ireland); Aldous v. Hicks, 2 I Ont. 95 (189r) (Canada).

70 Hart v. Chase, 46 Conn. 207 (1878). 
right; a right of indemnity; ${ }^{7 \mathrm{x}}$ the right of exoneration, i.e., to force the assuminggrantee to pay the mortgage debt; $7^{72}$ and to a limited extent in a few jurisdictions, the right to a release if, after the mortgagor so requests, the mortgagee fails to sue the grantee within a reasonable time.73 In so far as these courts have relied upon the similarity between the rights of the mortgagor and the surety to grant release because of an invasion of "rights" (e.g., taking away the "right of subrogation"), this reliance is open to the criticisms directed at the suretyship rule proper. ${ }^{74}$ Thus some courts, given the opportunity in mortgage cases to re-examine the reasons for release, have rejected the loss of the mortgagor's right of subrogation as a sufficient basis for release and have stated that his right of indemnity provides adequate self-protection. ${ }^{75}$ And other-courts have treated the increase in the mortgagor's risk as immaterial unless he can prove actual damage. ${ }^{76}$

Even though the mortgagor in an assuming-grantee case may seem very much like a surety, an additional reason may be suggested for not releasing him when an extension of time has been given the grantee. It has already been shown that release, except to the extent of injury, is usually refused to the more protected types of sureties-indemnified, compensated, and stockholder sureties. 77 The mortgagor does not gratuitously assume an obligation; rather he receives the benefit of a loan and is usually the principal debtor for a considerable time. Thus the mortgagor, not having entered into the original transaction primarily for the benefit of a third party, seems more like one of the better protected sureties and should only be released to the extent of his injury.

Where the grantee has assumed no personal liability but has only taken the land subject to the mortgage debt, the analogy is far more difficult to draw. The grantee has no obligation to pay the debt but has a choice of paying and retaining the land or allowing it to be foreclosed by the mortgagee, and so can-

$7 x$ Finzer v. Peter, I20 Neb. 389, 232 N.W. 762 (I930); 8 N.Y.U.L.Q. Rev. 5 II (I93I); 9 Neb. L. Bull. 453 (I93I). Depending on the terms of the contract, the right of indemnity in some states may be exerted even before payment by the mortgagor to the mortgagee. Morlan v. Loch, 97 Kan. 716, r49 Pac. 43r (r9x5); Callender v. Edmison, 8 S.D. 8I, 65 N.W. 425 (1895); Stichter v. Cox, 52 Neb. 532, 72 N.W. 848 (I897).

$7^{2}$ Marsh v. Pike, ro Paige (N.Y.) 595 (I844); Marshall v. Davies, 78 N.Y. 414, 422 (1879).

73 Russell v. Weinberg, 4 Abb. N.C. (N.Y.) I39 (I878); Birkhofer v. Krumm, 4 Cal. App. (2d) 43,40 P. (2d) 553 ( 1935 ); but Illinois has refused to extend the doctrine to mortgage cases. Fish v. Glover, I 54 IIl. 85,39 N.E. 1081 (1894).

74 See pp. 469-73 supra.

75 Iowa Title \& Loan Co. v. Clark Bros., 209 Towa I69, 224 N.W. 774 (I929); cf. Cacavalle v. Lombardi, 106 Conn. 539, I38 Atl. I55 (I927) (clearly upholding a right of the mortgagor to pay and sue notwithstanding an extension agreement).

${ }_{76}^{6}$ Teeters v. Lamborn, 43 Ohio I44, I N.E. $5^{13}$ (I885); Commercial Nat'l Bank of Charlotte v. Carson, 207 N.C. 495, I77 S.E. 335 (1934); In re Willock Estate, 58 Pa. Sup. Ct. 159, I69 (IgI4); Denison University v. Manning, 65 Ohio 138, 6I N.E. 706 (Igor).

77 See pp. 474, 475 supra. 
not be considered a principal debtor. Regardless of the fact that the mortgagor has a right against the land on his own mortgage by subrogation, in case the value of the land does not cover the debt, the mortgagor is still the principal debtor. And the mortgagor will only seek release if the land does not cover the debt. Courts construct a suretyship arrangement with too little difficulty by calling the land the principal debtor and the mortgagor, ${ }^{78}$ for whose personal debt the land is only security, a mere surety. On this basis, when an extension contract is formed between the grantee and the mortgagee, the mortgagor is released to the amount of the value of the land at the date the debt matured.79 This rule was developed not as a recognition that the mortgagor should be released only to the amount of his damage but because the courts reasoned that to this extent only was the mortgagor's right of subrogation destroyed. Thus even though the analogy is weak and the reason given by the courts questionable, the result in these cases is less indiscriminate than in either the assuming-grantee mortgage cases or in the accommodation surety cases. Here, the mortgagee gets the full benefit of his obligor's promise unless the value of the property becomes insufficient to cover the debt during the extension period.

In all mortgage cases, both where the land is taken subject to the mortgage and where the mortgage is assumed, the grantee usually pays the same amount for the land, i.e., the purchase price less the amount of the debt. In both the debt is closely connected with the land and in actual practice the mortgagor in either situation never expects after sale of the land to be called upon to pay any part of the debt. As previously developed, where the grantee has assumed the debt, there is no justification for releasing a mortgagor on the ground that an extension contract has destroyed a right which he would probably never use and which has little value. Especially is this true when the mortgagor has no knowledge of the extension agreement until the period has expired. ${ }^{80}$ But a valid extension agreement does decrease the possibility either of payment of the mortgage debt at maturity by the grantee or of foreclosure by the mortgagee at the highest possible price. ${ }^{8 \mathrm{x}}$ Thus although the mortgagor's risk has been increased, he is not entitled to release unless this risk has resulted in actual damage to him, and then only to the extent of his "damage." Since in the mortgage cases, the land is so intimately bound up with the debt, a workable rule would be to release the mortgagor only to the extent of depreciation in the value of the land during the extension period.

${ }^{8}$ See 25 IIl. Bar J. 206 (r937).

79 Murray v. Marshall, 94 N.Y. 6II (I884); Bunnell v. Carter, I4 Utah 100, 46 Pac. 755 (I896); contra, Shepard v. May, II5 U.S. 505 (1885); Chilton v. Brooks, 72 Md. 554, 20 Atl. I25 (189o).

${ }^{80}$ See Kazunas v. Wright, 286 Ill. App. 554, 4 N.E. (2d) 118 (I936).

8ะ Zastrow v. Knight, 56 S.D. 554, 564, 229 N.W. 925,930 (I930). 